Tyndale Bulletin 70.1 (2019) 117-143

\title{
CONGREGATIONAL MEMBERSHIP, CHURCH PURITY, AND PRESBYTERIAN AND CONGREGATIONALIST POLEMICS DURING THE PURITAN REVOLUTION
}

\author{
Yongkwon Chung \\ (peace1642@sejong.ac.kr)
}

\begin{abstract}
Summary
During the revolutionary decade of the 1640s, intra-Puritan conflict over ecclesiology, or the theological issue of church government, dominated the ecclesiastical landscape of England. Owing to the leading Puritans' lack of support for complete separatism as an ecclesiological alternative, the conflict pitted mainly the Presbyterians against the Congregationalists. This divergence of opinion over ecclesiastical system of governance has fascinated historians. Yet what this article finds is that, somewhat surprisingly, church purity, which was an issue closely linked to church system of governance and emerged as another highly contested theme vis-à-vis ecclesiology among contemporary polemicists, has not received the attention it deserves. Both Presbyterian and Congregationalist polemicists discoursed at length about the imperative of setting up pure churches, safeguarding the purity of churches from spiritual contamination, and maintaining the religious integrity of both its members and divine ordinances; yet, in many important ways, they differed over the precise means and mechanisms to achieve such a state of purity and integrity for the life of the church. It is hoped that a detailed examination of this theme of church purity as discoursed and debated by the Presbyterians and Congregationalists will add fresh perspectives on earlier works on religious conflict amongst the Puritans as it unfolded over the course of the revolutionary decade of the 1640s as well as the subsequent decade.
\end{abstract}




\section{Introduction}

Church government emerged as an explosive issue in England from the early years of the revolutionary decade of the 1640s. In a tract issued in 1641, the Presbyterian minister Thomas Edwards observed that 'the Great and Present Controversie of these Times is about the Church, and Church Government'. Edwards repeated the observation a little later in the tract - 'Now in our dayes in this Kingdome, the chiefe question is about the Church and the discipline of the Church'- and commented that the 'Controversie may fitly be tearmed the Disciplinary Controversie'. ${ }^{1}$ In 1640 to 1642 , the storm surrounding ecclesiastical polity involved primarily the issue of reformation of the established Church of England. Whilst some wanted to turn back the clock to the days of the later sixteenth century and Elizabeth I and merely rid the church of the 'popish' accretions built up especially over the course of the reign of Charles I from 1625 to 1640 , others wanted a more fundamental transformation in both church governance and worship. This conflict, representing the interests of the supporters of episcopacy on the one side and the interests of the advocates of 'Puritan' reformation on the other, receded to the background with the onset of internecine warfare in England in the summer of $1642 .{ }^{2}$ The ecclesiastical landscape of England from that time became dominated with intra-Puritan conflict over ecclesiology or the theological issue of church government. Owing to the leading Puritans' lack of support for complete separatism as an ecclesiological alternative, the conflict pitted mainly the Presbyterians against the Congregationalists. Thus, Presbyterianism and Congregationalism came to occupy centre stage in the ecclesiological drama that played out across the country during the $1640 \mathrm{~s}$ as well as the following decade. The main plank in the Presbyterian platform was a national church with authoritative and hierarchical assemblies or synods governing the life of the parishioners. Favouring a loose alliance of highly selective congregations, the Congregationalists advocated the right of self-government by

\footnotetext{
1 Thomas Edwards, Reasons against the Independant Government of Particular Congregations (London: 1641): epistle dedicatory.

2 For background to the England of the revolutionary decade, see Michael Braddick, God's Fury England's Fire: A New History of the English Civil Wars (London: Penguin, 2009); Clive Holmes, Why Was Charles I Executed? (London: Hambledon Continuum, 2006).
} 
individual churches without outside interference as a non-negotiable principle.

This divergence of opinion over ecclesiastical system of governance has fascinated historians. From the work of William Shaw in early twentieth century to the more recent writings by many church historians, including among others George Yule, Robert Paul, and Hunter Powell, one finds detailed and relatively comprehensive discussions to delineate the respective locus and exercise of church power as propounded by the two opposing ecclesiological camps. ${ }^{3}$ Yet what this article finds is that, somewhat surprisingly, church purity, which was an issue closely linked to church governance and emerged as another highly contested theme vis-à-vis ecclesiology among contemporary polemicists, has not received the attention it deserves. Both Presbyterian and Congregationalist polemicists discoursed, debated, and disputed at length about the imperative of setting up pure churches, safeguarding the purity of churches from spiritual contamination, and maintaining the religious integrity of both its members and divine ordinances; yet in many important ways they differed over the precise means and mechanisms to achieve such a state of purity and integrity for the life of the church. It is hoped that a detailed examination of this ecclesiastico-theological theme of church purity will add fresh perspectives to earlier works on the conflict amongst the Puritans and will pay dividends in terms of our understanding of the ideological dimension to the ultimate frustration of the Puritan hope for a unified religious settlement during the revolutionary decade of the 1640s. It is also hoped that, more broadly, the present study will enrich our understanding of the theological and ecclesiological disunity of the godly that compromised the stability of the Puritan republican regimes of the 1650s.

3 William A. Shaw, A History of the English Church during the Civil Wars and under the Commonwealth 1640-1660 (2 vols; London: Longmans, Green \& Co., 1900); George Yule, Puritans in Politics: The Religious Legislation of the Long Parliament 1640-1647 (Abingdon, UK: Sutton Courtenay, 1981); Robert S. Paul, The Assembly of the Lord: Politics and Religion in the Westminster Assembly and the 'Grand Debate' (Edinburgh: T\&T Clark, 1985); Hunter Powell, The Crisis of British Protestantism: Church Power in the Puritan Revolution, 1638-44 (Manchester, UK: Manchester University Press, 2015). 


\section{Congregationalists' Views on Church Membership}

In the spring of 1641, the Congregationalist minister Henry Burton advocated 'the new forming of a Church' that would be 'rightly ... constituted' by 'visible living members of Christ the head, and visible Saints under him'. This gathering of God's people separated from the ungodly formed the 'first degree' or the initial stage of religious reformation. The converse was also true for Burton, who argued that such a congregation would 'become a pure and holy people unto the Lord' precisely because it consisted of the 'precious' who have parted company with the 'vile'. ${ }^{4}$ For Burton's colleague and New England Congregationalist minister John Cotton, that idea of separateness as a prerequisite to purity was rooted in the very definition of the church. For him, the church was a 'Mysticall' society constituted by 'members and Saints called out of the World'. ${ }^{5}$ For that reason, Cotton restricted church membership exclusively to people set apart 'of God ... to the fellowship of Christ'. ${ }^{6}$ In a similar vein, the anonymous author of Satisfaction Concerning Mixt Communions Unsatisfactory asserted that 'a right Calling is required in a Congregation rightly gathered'.? Echoing these Congregationalists was another New England divine, Thomas Welde, who was residing in London at the time of the Revolution and found himself in the eye of the storm over the issue of the true meaning of a church. In his response to a Presbyterian pamphlet critical of the new colony's ecclesiastical makeup, Welde contended that the church is to be comprised of people 'Called to be Saints' and set apart 'first to the Lord' prior to signing up as a member of a church. Welde also commended some converts of the apostolic times who staged a dramatic open-air display of their decision to separate from the evils of the present world by 'burn[ing] as many

4 Henry Burton, The Protestation Protested or A Short Remonstrance Shewing What Is Principally Required of All Those That Have or Doe Take the Last Parliamentary Protestation (London: 1641): sig. B3.

5 John Cotton, The True Constitution of a Particular Visible Church Proved by Scripture (London, 1642): 1-4. William Rathband noted that this pamphlet was published in England by ' $\mathrm{M}^{\mathrm{r}} \mathrm{H}$. Peters'. See William Rathband, A Briefe Narration of Some Church Courses Held in Opinion and Practice in the Churches Lately Erected in New England (London: 1644): sig. A2.

6 Cotton, True Constitution, 4.

7 Anon., Satisfaction for Mixt Communions Unsatisfactory, or Some Short Animadversions Upon the Most Material Passages of a Late Book Entituled, Satisfaction Concerning Mixt Communions (London: 1643): 3. 
conjuring bookes as were worth no lesse then fifty thousand peeces of silver'. ${ }^{8}$

Besides spiritual separation, there was another important factor in the Congregationalist equation of ecclesiastical purity. In their Apologeticall Narration, Thomas Goodwin and four of his Congregationalist colleagues highlighted the significance of the 'qualification of the Members of Churches' and decried the 'promiscuous receiving and mixture of good and bad' by the church. ${ }^{9}$ To prevent such intermingling, Welde in his Answer to W. R. specified a set of criteria to restrict church membership to people who 'professed their faith ... believed in the Lord Jesus, with all their heart ... [were] men beloved of God ... Full of goodness, filled with knowledge'. ${ }^{10}$ Earlier in the pamphlet, Welde also thought that men of 'meeke and humble spirits and sincere ends' as possessing commendable 'spirituall stampe and character'. ${ }^{11}$ Such people who possessed Scriptureendorsed virtues would exhibit not merely 'externall holinesse' but 'reall and internall holinesse' requisite for ecclesiastical affiliation. ${ }^{12}$

Concomitant to the issue of clarifying the criteria for admission was to vet the person seeking it, for the obvious reason that the initial rationale for such criteria was to separate the wheat from the chaff. Moreover, most likely without exception, the Congregationalists backed the procedure of examination before admission. For example, Presbyteriall Government Examined advocated that not merely the 'Presbyters' but the entire 'commonalitie' of congregational members 'should take knowledge' of and inspect potential inductees to their church as to their 'holy profession of faith, and voluntary submission made as unto Christ himself, so to his most holy institutions in his church'. ${ }^{13}$ From a different perspective, Welde argued that many, who passed as 'sound' Christians in 'common view' prior to self scrutiny

8 Thomas Welde, An Answer to W. R. His Narration of the Opinions and Practices of the Churches Lately Erected in New England, Vindicating Those Godly and Orthodoxall Churches (London: 1644): 21-22.

9 Thomas Goodwin et al., An Apologeticall Narration, Humbly Submitted to the Honourable Houses of Parliament (London: 1644): 11.

10 Welde, An Answer to W. R. His Narration, 21-22.

11 Welde, An Answer to W. R. His Narration, 17.

12 Welde, An Answer to W. R. His Narration, 21-22.

13 Anon., The Presbyteriall Government Examined, Wherein the Weakness of Their Grounds are Unfolded. Also Their Pretended Proofes Disproved and the Liberty of the People in Chusing Their Owne Officers Proved Out of the Word of God (London: 1641): 6-7. 
and 'tryall by others', upon 'due' examination 'may be found too light, when weighed in Gods balance'. ${ }^{14}$ Welde himself agreed to a sort of a checklist that could be consulted for such a 'tryall', and the list included 'letters of recommendation', 'testimony of Members', 'experience of their conversion', 'knowledge and the work of grace', shared 'opinion and affection', residential proximity for 'mutuall watchfulnesse', and knowledge as well as approval of 'Church Covenant'. ${ }^{15}$ One function of such pre-screening was to ferret out people whose 'opinions be such as they destroy faith, or the power of holinesse ... or such as doe directly crosse and eradicate the fundamentalls of our Church Government'. Still the New England minister was willing to lower the bar, to mix metaphors, to wink at lesser spiritual shortcomings such as differences over 'some inferior points' of theology and ecclesiology as well as innate 'sowre and cynicall dispositions'. ${ }^{16}$ On the more practical level, Cotton conferred on the elders the authority to 'open, and shut the doores gf [sic] Gods House by admission of Members' ${ }^{17}$ Of course, that door would be opened only intermittently, that is when men and women with the necessary spiritual credentials came knocking on it, and after the elders had the time to assess them. Such a process of 'selection' was vital because the potential member, according to John Sadler, would be 'called to fellowship with the Saints as well as with the Father and the Son' upon acceptance by the congregation. ${ }^{18}$ That is why it was important for Sadler that the vetting process comprised of the 'consent of the congregation', no doubt for greater selectivity as well as because 'every one takes a charge upon' the new member 'as in respect of interest'. 19

It may be worth noting relative to this that the procedure for admission may have been helped by the principle of voluntarism, to which the Congregationalists subscribed. Burton believed that the privilege of church membership should extend only to the person who has 'freely' sworn a 'Covenant to observe all the condiditions [sic] and

\footnotetext{
14 Welde, An Answer to W. R. His Narration, 22.

15 Welde, An Answer to W. R. His Narration, 17.

16 Welde, An Answer to W. R. His Narration, 23.

17 Cotton, True Constitution, 3.

18 John Sadler, Flagellum Flagelli: Or Doctor Bastwicks Quarters Beaten Up in Two or Three Pomeridian Exercises, by Way of Animadversion upon His First Booke, Intituled Independency not Gods Ordinance (London: 1645): 16.

19 Sadler, Flagellum Flagelli, 18.
} 
orders thereof according to Gods Word'. ${ }^{20}$ Similarly, Cotton thought that only those who 'willingly offer and joyne themselves, first to the Lord and then to the Church ... by taking ... his holy Covenant' qualified as card-carrying members of a Congregationalist church. ${ }^{21}$ Welde explicitly linked the idea of covenant with that of voluntarism when he objected to the policy of receiving people to his congregation if they refused to take that spiritual pledge precisely because 'Gods people must be willing people'. ${ }^{22}$ Not all Congregationalists made covenant-taking mandatory or 'necessary' and a 'condition for admission' to a congregation, but even those in this camp such as Sadler believed that the person rejecting the covenant should exhibit 'a conscientious scruple' for the decision as well as an awareness of 'a special tye and relation for spirituall edification' with the congregation. ${ }^{23}$ This concern for covenant-based membership was reflected in their readiness to debar from their Lord's Table anyone who refrained from taking a covenant and chose to remain in the parish congregations, even when the Congregationalists considered them as constituting true churches. ${ }^{24}$

If potential members had to be vetted in advance, then those already belonging to a Congregationalist church also had to be watched over closely for the same reason of preserving a congregation of exemplary standing. For the purpose, the church again resorted to the eldership by assigning them pertinent duties. These obligated the elders to 'prevent and heale such offences in life, and Doctrine as might corrupt either their owne Church or other Churches', to 'see that none without the Church live either inordinately without a calling, or Idly in their calling', and to 'feed the flock of God with a word of admonition' ${ }^{25}$ In what the Congregationalists hoped would be exceptional cases, the

20 Burton, Protestation Protested, sig. C2.

21 Cotton, True Constitution, 4. The Presbyterians also understood such qualifications to be the hallmark of Congregational membership. See for example Alexander Forbes, An Anatomy of Independency, or A Briefe Commentary and a Moderate Discourse upon the Apologeticall Narration of Mr Thomas Good, Mr Philip Nye, etc. (London: 1644): 21.

22 Welde, An Answer to W. R. His Narration, 23. Italics added.

23 Sadler, Flagellum Flagelli, 18.

24 Adam Stewart, Some Observations and Annotations Upon the Apologeticall Narration Humbly Submitted to the Honourable Houses of Parliament, the Most Learned and Reverend Divines of the Assembly, and All the Protestant Churches Here in This Island and Abroad (London: 1644): 7.

25 Cotton, True Constitution, 3. 
elders may exercise their ecclesiastical authority to revoke the membership of 'notorious and obstinate offenders' unresponsive to admonitory measures and to show such persons the door. ${ }^{26}$ What the job description of the congregational elders thus indicates is that their activity for safeguarding the purity of the house of worship was more or less comprehensive, for it entailed not only admittance and expulsion but also what amounted to around-the-clock supervision that comprised activities designed to deter, discipline, and restore. To prevent dereliction of duty by the elders, the tract Satisfaction for Mixt Communions Unsatisfactory warned 'How liable then to Judgements are most Ministers, for their soule neglect to search out the offendors in their Assemblies. ${ }^{27}$ Additionally, for problems which went beyond the scope of the responsibility of a single congregational eldership, involved more than one church and might adversely affect spiritual purity, the Congregationalists devised a mechanism whereby all churches concerned would subject the party that 'differ[ed]' or presumed to have stirred up a hornet's nest to a 'most full $\&$ open tryall $\&$ examination'. ${ }^{28}$

The vision of church purity derived from limited and purged membership governed along Congregationalist lines was one of the reasons as to why the advocates of Congregationalism called into question the advisability of a national church, the membership of which encompassed the entirety of a given sovereign state, as was the case in England. Robert Coachman derisively referred to such a church as a 'stately religion' built upon a 'superstitious custome', ultimately giving false 'security' to the vast of majority of church members who remained blithely unaware of their deplorable spiritual condition. ${ }^{29}$ Goodwin and his Congregationalist colleagues asserted in their Apologeticall Narration that the 'power of godliness and the profession

\footnotetext{
26 Cotton, True Constitution, 3. Also see Sadler, Flagellum Flagelli, 11. Here the writings of the Congregationalists seem to suggest that some of them had to walk a relatively tight rope. For one thing, they did not want to fall on the side of those whose vision of ecclesiastical reform would, in their view, result in giving a free pass to anyone who was merely not 'notoriously' sinful to enjoy church membership. Yet for another thing, they saw the drawbacks of setting the admission bar too high, for it may disqualify the spiritually deserving from joining their congregation.

27 Anon., Satisfaction for Mixt Communions Unsatisfactory, 6.

28 Goodwin et al., Apologeticall Narration, 4.

29 Robert Coachman, The Cry of a Stone or a Treatise Shewing What Is the Right Matter, Forme, and Government of the Visible Church of Christ (London: 1642): sig. A3.
} 
thereof, with difference from carnall and formall Christians, had not been advanced and held forth among' the 'Reformed Churches', including those in England, almost all of which had been established along state lines. ${ }^{30}$ In basic agreement with Coachman and Goodwin, Burton also believed that, for a national church, such as the one advocated by the Presbyterians, 'it will be very difficult, if not rather impossible to constitute it so, as is agreeable in all points to a true and visible Congregation of Christ'. This inability to maintain a visibly pure church was primarily due to the spiritual temperament of the people of a given nation, most of whom were simply 'ignorant or profane'. Thus Burton refused to rest content with 'a bare profession' and 'a bare name' of 'Christianity' as a litmus test for membership in the church, because these would only 'degenerate' the church as well as the country's religion. ${ }^{31}$ More disapproving was Coachman, for whom a national church was an institution not 'appointed' or established by 'Christ or his Apostles' and hence unwarranted by Scripture. ${ }^{32}$ Such severe stances notwithstanding, the Congregationalists as we shall see did not deny that the national church of England and its myriad of parish congregations constituted true churches. ${ }^{33}$

\section{Presbyterians' Views on Church Membership}

By contrast, the Presbyterians accepted as axiomatic the legitimacy of a national church that included as its members all the inhabitants of a given territorial state and that prohibited ecclesiastical gatherings outside that church. ${ }^{34}$ Unlike the Congregationalists, the Presbyterians believed that mixed membership, inevitable for a national church, was to be borne with rather than completely eschewed. Edwards remarked

30 Goodwin et al., Apologeticall Narration, 12-13.

31 Burton, Protestation Protested, sig. B3 and sig. C2.

32 Coachman, Cry of a Stone, sig. A2.

33 Even a harsh critic like Coachman was in reality a typical semi-separatist. However much he wanted to do away with the Presbyterian church government, Coachman was unwilling to refrain from fellowship with parish congregations, or what he referred to as the 'old Temple'. Coachman, Cry of a Stone, sig. A2. Also see Goodwin et al., Apologeticall Narration, 6-7.

34 Edwards, Reasons against the Independant Government, 27; D. D. P., An Antidote Against the Contagious Air of Independency Shewing I. Six Sufficient Grounds, Why They Ought to Revoke Their Schismaticall Principles. II. Six Parallels Betwixt Theirs and the Jesuiticall Practices (London: 1645): 14-17; Forbes, Anatomy of Independency, 14. 
that even if the national church were reformed, it may be that 'there will be but evill men suffered' in the church. Nonetheless, the polemicist differentiated such men from those 'of the most profligate life' who presumably would be excluded from church fellowship. ${ }^{35}$ Even the Congregationalists, the author of Antidote Against the Contagious Air of Independency protested, would be unable to 'obtain ... private congregations ... so pure as to be free all Hypocrites, Profane, or ill prepared receivers [of the Communion]' even if such congregations 'should ... separate every month and change their private congregations'. ${ }^{36}$ The tract then referred to 'Judas, the son of perdition' among the twelve disciples of Jesus Christ and to one 'Atheist' among the 'four men' on Noah's ark to illustrate the idea that spiritual perfection in Christian communities was virtually impossible to realise in the present world. Therefore the Congregationalists should not seek perfected purity against the better judgement of Scripture. ${ }^{37}$ Ecclesiastical perfection was an ideal not meant for actualisation in a fallen world.

In his rebuttal of the Congregationalists' arguments for selective membership that constituted the key basis of their opposition to a national church, Forbes drew attention to what he believed was a generally acknowledged fact that they debarred people from joining their churches whom most of the other 'Reformed Churches acknowledge warrantable to receive' as members. ${ }^{38}$ For the Scottish polemicist, one of the main reasons for the dissimilar treatment of potential members could be found in the Congregationalists' excessive scrupulosity. This had led them to preclude as church members the 'tender hearts', who despite 'their exemplary conversation ... dare not professe themselves to be converted, and so to proffer themselves to the church in their desire of enjoying ordinances of Christ' ${ }^{39}$ Forbes then asserted that 'most Churches thinke it the safest way to hazard to erre rather in the excesse, then in the defect of charitie' ${ }^{40}$ In other words, those who are weak in faith or who display merely some spiritual failings should be given the benefit of the doubt.

35 Edwards, Reasons against the Independant Government, 40.

36 D. D. P., Antidote Against the Contagious Air of Independency, 9.

37 D. D. P., Antidote Against the Contagious Air of Independency, 9-10.

38 Forbes, Anatomy of Independency, 30.

39 Forbes, Anatomy of Independency, 31.

40 Forbes, Anatomy of Independency, 31 
Subsequently, Forbes changed tack and went on the offensive, attacking the Congregationalists' own claims that they 'took measure of no mans holinesse by his [religious] opinion, whether concurring with them, or adverse unto them' ${ }^{41}$ Recognising that they limited such opinion to that of the 'Protestants', Forbes still could not take such apparent generosity at face value because the same Congregationalists did not accommodate among others people who were 'of the opinion of Presbyteriall Government' for refusal to 'submit ... to their [Congregationalist] government'. ${ }^{42}$

Similarly critical of what he perceived as overly strict criteria for admission employed by Congregationalist churches, William Rathband contended that there were two kinds of 'holinesse' which should be taken into consideration. One was 'externall and federall holinesse', and the other was 'reall internall holinesse'. The latter, which Rathband also referred to as 'morall' holiness, was required of all God's people, for it was a divine mandate that had to be fulfilled 'unto acceptation with God'. The former was 'absolutely necessary to Church estate' and to the 'meere being of the Church'. Put differently, 'real' or 'moral' holiness was not a prerequisite to 'admission into the church', while 'external' holiness should be regarded as an existential characteristic of the church'. ${ }^{43}$ Hence, for Rathband, it was the error of the Congregationalists to apply 'real' holiness as an acid test of church membership rather than of true sainthood in Christ. Rathband also cast doubt on the ability of the Congregationalists to judge omnisciently whether a certain person was holy and worthy enough to be received as a fellow observant of divine ordinances and posed several questions. First, Rathband asked, '[B]y what rule wee should estimate ... their holiness'? Second, whether the 'inquirie' of a potential member should be such that the church should deem 'all faire overtures and shewes of Grace ... sufficient, for ... admission'? Or third, whether the church should 'more narrowly search and sound mens hearts to the bottome'? Of course, Rathband would have rejected all hypothetical responses from the Congregationalists in favour of the 'rule of a large charitie which beleeveth and hopeth all things, judging all them to be sanctified that doe not give convincing and unquestionable proofe of the

41 Forbes, Anatomy of Independency, 32.

42 Forbes, Anatomy of Independency, 32.

43 Rathband, Briefe Narration, 5-6. 
contrary'. Analogous to Forbes' ideas, the notion of charity 'that suspects no evill' was placed on the pedestal as a rationale for an inclusive national church. ${ }^{44}$

In light of the above strong opposition to exclusivist membership, the Presbyterians naturally refused to accept the Congregationalist practice of covenant taking that was symbolic of not only voluntarism but also exclusivism. For the Presbyterians like Edwards, the idea of requiring people to take the covenant as a prerequisite for church membership lacked more than anything else Scriptural warrant either by way of a clear 'precept' or illustrative 'practice' ${ }^{45}$ For other Presbyterians, the purity of the church could not be maintained on the principle of voluntarism as embodied in covenant taking not only for the Congregationalist churches but also for other separatist groups, some of which sought shelter under the protective wings of an ad hoc policy of toleration granted to Congregationalism. ${ }^{46}$ Antidote Against the Contagious Air of Independency complained about membership covenants for another reason, namely that some churches required it to constrain members to 'contribute to the necessities of their Pastors'. Moreover, those churches had their people subscribe to an 'oath or promise to follow him [pastor] wheresoever he is inforced to flee; whether it be in Holland or in America'. In addition to the 'rents' or imbursement for lectures, this twofold insurance for the Congregationalist divines, the tract complained, made certain that their annual 'revenew doth excel the yeerly coming in of the best parish Cures'! 47

Both covenant-based membership and selective congregational admittance failed to assure the church of spiritual purity for Adam Stewart, who offered an interesting perspective on the issue. Stewart argued that the initial exhilaration derived from setting up new congregations upon a fresh set of ecclesiological principles would eventually wear off to frustrate the Congregationalist vision of spiritual purity. Stewart explained:

Neither do we deny, but a number of very holy persons may be gathered together, who may so carrie themselves for some time, as not to commit any great offence with pertinacie, to deserve Excommunication, if the

\footnotetext{
44 Rathband, Briefe Narration, 6-7.

45 Edwards, Reasons against Independant Government, 12.

46 Edwards, Reasons against Independant Government, 33-34.

47 D. D. P., Antidote Against the Contagious Air of Independency, 18.
} 
choice be good. But to say, that it may last long so in Populous Congregations, and in a great number of Churches, ye may tell us this news, when you Churches are multiplied, and become as Populous, and have endured as long as ours. We could tell wonders also of our Churches in some parts; in the beginning of the Reformation. ${ }^{48}$

Stewart then concluded this brief discourse with a reminder on the issue in contention that 'the question is not, who liveth, holiest, but whose Discipline is most conform unto Gods Word? ${ }^{49}$ Over against the Congregationalists' commitment to a system of autonomous and selective congregations as a bulwark for spiritual purity, Stewart insisted that the 'power of godliness' or holiness of churches was not a function of ecclesiastical structure and 'Government'. This meant that an ecclesiastical system organised along Presbyterian lines generally exercised negligible influence on the purity of the church. The same line of reasoning would naturally apply for Congregationalist ecclesiastical structure. Hence it was not a matter of one ecclesiastical system, whether inclusive and national or exclusive and congregational, being 'better' or 'worse' than the other when it came to the conservation of church purity. Rather it was the 'fault of ... the Divell, of those that govern, or are governed' that churches lacked godliness. In other words, the responsibility for the integrity of the church rested with personal, rather than institutional, agency..$^{50}$ Forbes concurred when in his discourse against Congregationalism he reminded his readers that 'evill men may live under a good government' and that 'the power and practise of Godlinesse' were the outcome of the 'free grace of God, and a powerfull and sound dispensation of the Word' rather than of '[church] Government'. ${ }^{51}$ Hence for the Presbyterian polemicists, two churches theoretically could have decidedly contrasting spiritual complexion even if they both belonged to the same ecclesiastical system, given that how competently and willingly the congregation and its leadership dealt with doctrinal and ethical aberrations determinatively impacted religious purity. It was for the above reason among others that the Presbyterians would have agreed with the Congregationalists that it was the job of the spiritually qualified ruling elders to administer ecclesiastical discipline,

\footnotetext{
48 Stewart, Some Observations and Annotations, 20.

49 Stewart, Some Observations and Annotations, 20.

50 Stewart, Some Observations and Annotations, 14. Also see Goodwin et al., Apologeticall Narration, 4.

51 Forbes, Anatomy of Independency, 9-10.
} 
including excommunication of unworthy members. In other words, simply any eldership would not do. That is, those elders with evidences of divine grace at work in them in the form of holiness and dedication had to exercise the function of an overseer if the congregation were to keep worldly impurities at bay. It was with this in view that the tract Sacramental Stumbling Block Removed specified that the elders' job was to 'govern and direct ... chiefly them that walk after the flesh in the lust of uncleannesse', to 'keep the Doctrine, Discipline, and Ordinances, of the Church from corruption' and to 'suspend the unworthy from the Sacrament of the Lords supper'. ${ }^{52}$ Still, as we shall see, the Presbyterians left room for the persons facing an ecclesiastical discipline to appeal to assemblies beyond the level of congregational eldership or consistory such as the presbytery or classis, provincial synod, and national synod or general assembly. ${ }^{53}$

Most contemporary Presbyterian thinkers would have agreed with the above postulation that human contribution outweighed institutional configuration when it came to the spiritual upkeep of congregations. Yet this did not mean that ecclesiastical polity was left out of the equation altogether. Antidote Against the Contagious Air of Independency engaged in a two-pronged attack on Congregationalism by first showing its deficiencies and second highlighting Presbyterianism's virtues, both with reference to spiritual purity. One of the main issues the tract had with Congregationalism was the autonomy of a given church. By precluding the exercise of external authority over individual congregations, such an autonomous system would give rise to 'Tyrants' in the form of pastors and elders 'to be absolute over their congregation'. Such men would have little qualms about 'impiety' or 'Heresies' if these spiritual impurities served the purposes of consolidating their power, wealth, and reputation. ${ }^{54}$ It was precisely because Presbyterianism discountenanced congregational autonomy in favour of congregational dependency that it was able to 'keepe the Clergy in that purity of Doctrine and Discipline' and by extension the congregation members as well. Such dependency,

52 W. L., The Sacramental Stumbling Block Removed. Or a Brief Discourse Concerning Examination by the Congregational Eldership, before Admittance to the Sacrament (London: 1648): 5-9, esp. 5-7.

53 Edwards, Reasons against Independant Government, 8-10, 17-19; Forbes, Anatomy of Independency, 33-52.

54 D. D. P., Antidote Against the Contagious Air of Independency, 14-15. 
according to Antidote Against the Contagious Air of Independency, entailed individual congregations overseen by 'twelve Classis' composed of 'six Reverend Divines, appointed to call twice a year all the Pastors under their Jurisdiction before them'. The purpose of the gathering was to 'examine and determine of all Cases as well for Doctrine, Discipline, and misdemeanour in life and conversation'.55 Likewise, the tract Appeale to Every Impartiall, Judicious, and godly Reader explained how the oversight council of the presbytery or classis made certain that 'the life and doctrine, the diligence of Ministers (within the Presbytery) is look'd into, and so the lives and behaviours of their elders, and the disobedience of anyone to the Session, is with authority censured' upon appeals made from the consistories. Hence the scope of responsibility of the presbytery was rather comprehensive, for it included the spiritual life and purity not only of the church leadership such as 'Ministers' and 'elders' but also of 'anyone' or the ordinary men and women of the parish. ${ }^{56}$ The council occupying the next rung on the hierarchical ladder of Presbyterian church governance, the provincial synod, concerned itself with church purity, according to the Scottish minister Alexander Henderson, primarily by examining each presbytery 'if there bee any knowne scandal, fault, or negligence amongst them'. Henderson also noted that 'all the members of the Presbyteries suffer the like inquirie'. ${ }^{57}$ At the apex of Presbyterian polity stood the national synod the main task of which was the 'judg[ing] of the Appeals, and of the greater affaires of the Church', no doubt for the purposes of maintaining the integrity and discipline of all congregations affiliated with the national church. ${ }^{58}$

\section{Congregationalists and the Purity of the Lord's Supper}

The Congregationalists regarded purged membership for the church highly important not only for its own sake, as we have seen, but also for its interrelated spiritual ramifications, foremost of which had to do

55 D. D. P., Antidote Against the Contagious Air of Independency, 16-17.

56 Anon., An Appeale to Every Impartiall, Judicious, and Godly Reader Whether the Presbyterie or Prelacie Be Better Church Government (London: 1641): 9.

57 Alexander Henderson, The Government and Order of the Church of Scotland (Edinburgh: 1643): 31.

58 D. D. P., Antidote Against the Contagious Air of Independency, 17. 
with divine ordinances. For Cotton, such ordinances were comprised of primarily the 'Word and Sacraments'.59 Goodwin and his Congregationalist colleagues regarded 'Publique Prayer' as a 'great ordinance' ${ }^{60}$ Burton expanded the relatively brief list by referring to Old Testament Israel's 'Oblations, their Sabbaths, their solemne assemblies' as 'Gods Ord[inances]', which suggests that the Congregationalist minister would have considered church offerings, the Lord's Day, and gatherings for worship of his own day as divinely instituted ordinances. ${ }^{61}$ These ordinances, the Congregationalists believed, had to be safeguarded from spiritual defilement and were profoundly affected by the spiritual state of the people sitting in the pews. For the Congregationalists, the maintenance of the divine ordinances in a state of purity had the purpose, among others, of procuring salubrious congregational fellowship. In somewhat of a circular reasoning, Burton in Protestation Protested reminded his readers of the importance of 'draw[ing] neere unto Christ in a holy Communion with him in the purity of his Ordinances'. That observation indicates that for Burton the 'purity' of church ordinances formed an indispensable milieu in which the people enjoyed 'holy' fellowship with Christ. ${ }^{62}$ In other words, ordinances which have been defiled for instance by the addition of 'mens inventions' or by the participation of wicked persons would adversely affect a believer's spiritual relationship with Christ and by extension with people belonging to Christ. For Cotton, mutual instruction among the members of the church was predicated upon undefiled administration of divine ordinances because the believers 'edifie one another in all his holy Ordinances' ${ }^{63}$ It was no doubt for those reasons that Goodwin and his colleagues in their justification of Congregationalism were careful to draw attention to how their 'publique worship was made up of no other parts then the worship of all other reformed Churches doth

\footnotetext{
59 Cotton, True Constitution, 9.

60 Goodwin et al., Apologeticall Narration, 12.

61 Burton, Protestation Protested, sig. B3. Cotton also referred to collection of offerings as an 'ordinance'. See his True Constitution, 7. Although the views of Burton, Goodwin, and Cotton appear to have prevailed among the Congregationalists, some men from the same ecclesiological camp, like John Sadler, limited divine ordinances to the sacraments and ecclesiastical censures. See Sadler, Flagellum Flagelli, 3.

62 Burton, Protestation Protested, sig. B3.

63 Cotton, True Constitution, 1.
} 
consist of' and that Cotton limited church membership to the '[s]aints'. ${ }^{64}$

Nevertheless, the issue of church purity placed itself at the top of the Congregationalist agenda arguably because of its perceived effect on the ordinance of the Lord's Supper. In Protestation Protested, Burton asserted that the believers would become 'guilty of the same prophanation [of the Lord's Table]' as that committed by the 'profane and ignorant persons' if both partook of the same Table. ${ }^{65}$ From a somewhat different perspective, but still on the same page as Burton, Satisfaction Concerning Mixt Communions Unsatisfactory asserted that by sharing the Lord's Supper with the ungodly and by showing 'no dislike of them' the saints 'doe countenance and confirme them in their sin'. What is more, by 'joyning' with the 'rotten and leprous members', the saints not only sin themselves but also become guilty of a 'greater' $\sin .{ }^{66}$ The tract went on to argue that 'the more godly and knowing a man is, he doth in this case sin the more, for he emboldneth not onely the wicked in his way, but also the weak Christian, who otherwise is offended by communicating with such profane companions'. ${ }^{67}$ Moreover such a cacophonous intermingling 'exhibited' Christ 'destructively to the Communion in the Sacrament; to the godly with scandall; to the profane, to seal up their damnation'. ${ }^{68}$ Another domino effect of such 'admitting' of the profane 'promiscuously to communicate with godly persons' was to give false confidence to the former that 'they are as holy as the best, when with them they are made equal partners of those holy things' ${ }^{69}$ It was precisely for such reasons that the tract complained of the 'common and ordinary Parochiall Congregations, consisting of good and bad, without difference, without order, without discipline' and instead advocated a 'purest way of Reformation' free from such a disagreeable intermixture. ${ }^{70}$

For some Congregationalists, the sacrament of the Lord's Supper constituted the one ordinance that surpassed all others when it came to the level of seriousness with which divine ordinances were to be

64 Goodwin et al., Apologeticall Narration, 8; Cotton, True Constitution, 1.

65 Burton, Protestation Protested, sig. B3.

66 Anon., Satisfaction for Mixt Communions Unsatisfactory, 4-7.

67 Anon., Satisfaction for Mixt Communions Unsatisfactory, 13.

68 Anon., Satisfaction for Mixt Communions Unsatisfactory, 4.

69 Anon., Satisfaction for Mixt Communions Unsatisfactory, 4.

70 Anon., Satisfaction for Mixt Communions Unsatisfactory, 9-14. 
guarded from defilement. When referring to the scriptural passage on the 'holy things not to be cast to dogs', Satisfaction Concerning Mixt Communions Unsatisfactory remarked that 'rather the Sacrament [of the Lord's Supper] then other holy things: For profane persons are admitted ... to heare the Word, but not so to the Sacrament'. In other words, the tract was prepared at least to recognise the de facto practice of 'admitt[ing]' the 'profane' and the 'excommunicate' to hear preaching from the pulpit whilst rejecting flat out the idea of their coming to the Lord's Table..$^{71}$ The implication of such a view was that the author of the tract would not have debarred the 'profane' from other ordinances such as public prayers and collection of offerings when the same persons had already been 'admitted' to the church to hear ministerial preaching. The Presbyterians agreed on this question, as in the Presbyterian tract Sacramental Stumbling Block Removed one finds an argument that 'although all men ought to hear the word, yet neither the ignorant nor prophane ought to be admitted to the Sacrament of the Lords Supper'. ${ }^{72}$ Another Congregationalist polemicist, Sadler set apart 'communion in the Lords Supper' as a form of spiritual fellowship too special to countenance its indiscriminate employment, rather reserving it 'ordinarily' for the saints of Congregationalist churches. This confirmed the generally shared Congregationalist stance at the time that the constituents of the same congregation ought to participate in the divine ordinances on a regular basis. Even if the sacrament of the bread and wine occupied a special place in Sadler's theological construct, he did leave room for one exception when he granted its 'occasional' utilisation with other non-Congregationalist church members if the latter 'walk[ed] up to their light'. ${ }^{73}$ Perhaps it was for the same reason of distinctiveness of the sacraments that Sadler categorised 'praying, hearing [of sermons], conference, admonition' as 'common duties of Religion' rather than as 'Church-ordinances' and that he saw no difficulty for the Congregationalists to engage in spiritual fellowship with non-Congregationalist believers in such 'duties'. ${ }^{74}$

\footnotetext{
71 Anon., Satisfaction for Mixt Communions Unsatisfactory, 2.

72 W. L., Sacramental Stumbling Block Removed, 2.

73 In other words, if such congregations conducted themselves according to the requirements of the 'light' or revelation of Scripture. See Sadler, Flagellum Flagelli, 3. 74 For Sadler, the sacraments or ordinances were comprised of the Lord's Supper and baptism. Also as mentioned, divine ordinances included ecclesiastical 'censures'. See Sadler, Flagellum Flagelli, 3, 11.
} 


\section{Presbyterians and the Purity of the Lord's Supper}

Like their Congregationalist counterparts, the Presbyterians exhibited keen awareness of the need to safeguard the purity of the ordinances especially the Lord's Supper. ${ }^{75}$ John Vicars furnished one important reason for maintaining such an attitude. For him, 'it cannot be denied by any that the Word of God soundly preached, and the Sacraments purely administered, are Gods Field of Corn, his precious Vineyard, and his Garden of fragrant Flowers and wholesome Herbs'. The imagery of God's direct involvement as a 'provident Gardiner [sic] or Husbandman' in the rhythms of church life beating most conspicuously in the administration of the divine ordinances of preaching and sacraments was no doubt employed to remind the reader of the indispensability of purity accompanying the Lord's Supper, among other ordinances. ${ }^{76}$ Perhaps it was in light of such cognisance that Edwards considered as legitimate the objections of the Congregationalists against the widespread practice of turning a blind eye to 'scandalous' persons partaking of the Lord's Supper in the Episcopal church prior to 1641 . The Presbyterian polemicist remarked how alienation to such a practice was 'the reason why' the Congregationalists 'first left our Churches' in England. Yet the Presbyterian minister was quick to draw attention to how the efforts to reform the church by the Puritans would divest the Congregationalists of one of their chief grounds for separation, because they 'may without danger shew ... dislike and speake against scandalous persons, and against the fault of the Church, if they admit such to the Sacrament'. The end result of that liberty to lodge objections would be that 'either such persons will be wholly kept away, or else you [Congregationalists] may protest against them', presumably to achieve the same result of exclusion from the Communion table. ${ }^{77}$ Printed in 1648 when the Assembly of Divines at Westminster completed their blueprint for Presbyterian doctrine, worship, and government, Sacramental Stumbling Block Removed similarly recognised the necessity to establish strict criteria for admission to the sacrament of the Lord's Supper and sought to justify the Assembly's rules drawn up for that purpose. To the objection that the Lord's Table should be kept off

\footnotetext{
75 Edwards, Reasons against Independant Government, 39.

76 Vicars, Schismatic Sifted, 4.

77 Edwards, Reasons against Independant Government, 41.
} 
limits only to the 'scandalous' and not the 'ignorant', the tract responded that '[i]gnorance as well as scandal make men uncapable: for ignorant men are not able to discerne the Lords body'. The tract then shifted gear to an even stronger criticism:

Nay, men ignorant and erroneous, are more dangerous in the church, then the scandalous: for the scandalous is palpably known to himself and others, to be in an undone condition: but an ignorant man, or a man of corrupt judgement in fundmentalls, doth not only go himself hud-winked to hell, but if God be not the more mercifull, draws others along with him. ${ }^{78}$

The tract then went on to provide a succinct summary of doctrines the knowledge of which should be required of every recipient of the Lord's Supper, as well as an enumeration of 'scandals' subject to sacramental exclusion. ${ }^{79}$ Moreover, it was for the purposes of impartially keeping out both the theologically ignorant and religiously scandalous that the tract advocated the practice of parishioners 'com[ing] before the Eldership to be examined before admittance' to the Table rather than having 'some men of best rank' make house visitations and converse with its members for spiritual evaluation. ${ }^{80}$ The author of the tract recognised that even with such safeguards as strict criteria and examination before eldership there would still be 'many corrupt men [who] will be admitted to the Table'. Nonetheless, 'if men were admitted hand over head, as formerly, without Examination', the author explained, then 'much more would be corrupt' relative to the ordinance itself. 81

Along this vein, the tract Antidote Against the Contagious Air of Independency criticised the 'carelesnesse' of the eldership that 'admit notorious sinners to so blessed a Sacrament, for they cannot be too precise to examine such as they suspect to be of scandalous life, or to refuse them the admittance'. Such a strict screening procedure was intended to weed out unworthy persons 'until they give to the world clear evidence of their conversion and amendment of life'. Yet the tract was equally critical of those removing themselves from 'their Parish Congregations, because of some few known sinners are admitted to the Sacrament of the Lords Supper by the carelesnesse of the Pastors,

\footnotetext{
78 W. L., Sacramental Stumbling Block Removed, 29.

79 W. L., Sacramental Stumbling Block Removed, 38-42.

80 W. L., Sacramental Stumbling Block Removed, 35.

81 W. L., Sacramental Stumbling Block Removed, 29.
} 
Church Wardens, or Elders' ${ }^{82}$ Additionally, the tract posited a subtle distinction to shore up its argument when it recognised two levels of spiritual separation. One was 'peculiar separation' and the other 'Publike or a general separation'. The former was to be encouraged, because it presupposed an awareness that 'there is nothing more dangerous for a Christian to inhabit, or to be familliarly [sic] acquainted or conversant with Sectaries, profane, Licentious, and impious men' and thus entailed withdrawing fellowship from them at the personal level. The latter 'general separation', however, was to be eschewed, for it was scripturally unwarranted to 'separate ourselves from the Church, but upon palpable errors, that are crept, or wilfully maintained (as they are in the Church of Rome) against the Analogie of Faith, and the true Orthodox Doctrine of the best Reformed Churches of Christendom'. Such a removal from the established 'Church' at an institutional level would be to 'to rent in pieces ... the Mysticall Body of Christ' ${ }^{83}$

The anonymous author of Satisfaction Concerning Mixt Communions provided a more focused, theoretical defence of the projected practice of a relatively open celebration of the Eucharist in the church to be reformed by the Westminster Assembly and the parliament. Echoing the aforementioned Presbyterians, the tract affirmed as a basic premise that it was in agreement with the Congregationalists on the need to debar 'wicked' and 'unfit' persons from the Lord's Table by employing appropriate devices of 'proof' and 'censure' as necessary. ${ }^{84}$ Yet the concurrence evaporated as soon as the more pressing question of whether 'their undue coming [to the Table]' presented a 'sufficient ground' for the spiritually qualified 'to keep away' from it. ${ }^{85}$ The pamphlet offered a resounding no as its response to the query. First, the pamphlet reasoned that a 'Civill Body may be politikely guilty by one ... but in the conscience, thousands cannot defile one, no where, and least of all in the Ordinances of God; which is my Sanctuary, and so every faithfull mans' ${ }^{86}$ In other words, a godly

82 D. D. P., Antidote Against the Contagious Air of Independency, 10.

83 D. D. P., Antidote Against the Contagious Air of Independency, 9, 11.

84 Anon., Satisfaction Concerning Mixt Communions: In Answer to the Doubts of Some Who Abstain from the Sacrament of the Lords Supper Because Wicked Persons are Present (London: 1643): 1, 4.

85 Anon., Satisfaction Concerning Mixt Communions, 1.

86 Anon., Satisfaction Concerning Mixt Communions, 7. 
person can partake of all divine ordinances including the Lord's Supper without having to agonise over whether he or she would become defiled by an ungodly person also participating in them unwittingly due to an absence of close ecclesiastical supervision. ${ }^{87}$ Antidote Against the Contagious Air of Independency was of like mind as it succinctly declared that 'it is certain that the guilt of an impenitent receiver is not transferred upon the well prepared receiver, for if it were, Gods promises were in vaine, and to think so were blasphemy'. The tract made a reference to Ezekiel 18:19,20 in the margins as proof text in support of that view, as the biblical passage stipulated individual responsibility for personal sins as well as their non-transferability to other persons. ${ }^{88}$

Looking at the issue from a slightly different angle, Forbes maintained that the 'ground of communion in Government, as well as in Sacraments, and other Ordinances' was not necessarily congregational purity but 'visible union' ${ }^{89}$ Such unity no doubt was achieved by the Presbyterian system of governance, which visibly bound together all the congregations of England as a unified church. Rathband cast doubt on the Congregationalists' claims to pure and undefiled administration of the Lord's Supper based on their policy of segregation of the regenerate from the unregenerate by arguing that even those who 'perhaps ... have the truth of grace' and were thus 'admitted' as members may yet harbour 'secret sinnes' which still defiled the sacramental communion and its participants irrespective of any successful implementation of other precautionary measures. Rathband then concluded this line of reasoning against Congregationalism by posing the rhetorical question '[W]ith what societie can a man joyne to be assured not to be defiled?'90

87 The pamphlet thereafter developed a line of argumentation drawn from relatively extensive references to as well as his reading of relevant scriptural verses to build a case against the sacramental exclusivism of his Congregationalist counterparts. Anon., Satisfaction Concerning Mixt Communions, 3-14.

88 D. D. P., Antidote Against the Contagious Air of Independency, 10.

89 Forbes, Anatomy of Independency, 45.

90 Rathband, Briefe Narration, 36. 


\section{Presbyterians, Congregationalists, and the Purity of Divine Ordinances}

Although the focus of the controversy revolved primarily around the ordinance of Communion at the Lord's Table, the Presbyterian and Congregationalist polemicists also addressed other ordinances, albeit less frequently and often in more general terms. Satisfaction Concerning Mixt Communions referred broadly to the 'Ordinances of God' when putting forward the argument that the saints cannot be tainted by the sins of the wicked even when they jointly partake of such ordinances. ${ }^{91}$ Taking a similar stance, Forbes referred to the Congregationalists' view 'that to communicate with wicked men or such as uphold any sinfull course, even in the good and Lawfull ordinances of God, doth polute us, and make us partakers of their sinnes' as a 'miserable principle'. Forbes then remarked that such a view was the 'maine rock whereon they have made shipwrack in their Separation from the Church of England'. ${ }^{92}$ More specifically, the Scottish polemicist exhibited concern for maintaining the purity of doctrine, which is inextricably tied to the ordinance of preaching. In this respect, the Presbyterian system of appellate ecclesiastical courts comprised of presbyteries and synods functioned as a 'wall to preserve her in Doctrine, and therefore a small breach there even by small differences, may make way for greater, even in Doctrine' ${ }^{93}$ In other words, a fully operating Presbyterian system of governance would serve as a bulwark for doctrinal purity.

The Congregationalists begged to differ, however. Satisfaction Concerning Mixt Communions Unsatisfactory argued that persons with 'knowne sins' can 'make others guilty' when both participate concurrently in 'Gods Ordinances'. ${ }^{44}$ In a similar vein, Burton contended that because to interact or "communicate with known evill doers which even in their presuming to communicate in the Ordinances, do evil in their doing of evil', the godly actually shared in 'their evil deeds' when they 'communicate[d]' with them. ${ }^{95}$ For Welde, a 'pure Church' was characterised by people who 'walke in all the holy

\footnotetext{
91 Anon., Satisfaction Concerning Mixt Communions, 7.

92 Forbes, Anatomy of Independency, 50, 51.

93 Forbes, Anatomy of Independency, 52.

94 Anon., Satisfaction for Mixt Communions Unsatisfactory, 6.

95 Burton, Protestation Protested, sig. B3.
} 
ordinances of God ... [a]ccording to the will of God ... [i]n one Congregation'. ${ }^{96}$ Thus it is not surprising to find the minister concurring with the view that 'in such parish assemblies where a man shall and must (himself) conforme to ... corruptions, there his standing is unlawfull' and therefore he has just 'ground[s]' for 'withdrawing' from them. ${ }^{97}$ Furthermore, to steer clear of such defilement of Congregationalist churches, Welde recommended that a letter of recommendation be obtained prior to administering 'Church ordinance' to visitors unless they were already 'known to any of our Church' ${ }^{98}$ There seems to have been a certain level of inconsistency among the Congregationalists at least, as discussed above, when Satisfaction Concerning Mixt Communions Unsatisfactory would not debar wicked persons from hearing the Word but prohibit them from coming to the Lord's Table even whilst both were considered by them as divine ordinances.

\section{Presbyterian and Congregationalist Controversy During the 1650s}

There is some evidence that the controversy over the purity of congregations and ordinances spilt over into the next decade of the 1650s. In 1650 for instance, two tracts were issued addressing, among others, the question of the ordinance of the Lord's Supper and its administration to a congregation exhibiting a mixture of saints and the unholy. The well-known Congregationalist clergyman Nathaniel Holmes entitled his work The Mischiefe of Mixt Communions while the Presbyterian minister Henry Jeanes published his pamphlet under the title The Want of Church Government No Warrant for Totall Omission of the Lords Supper. Although carrying suggestive titles, neither of the tracts offered fresh perspectives on the question in any consistent manner. Rather, they generally contained rehashing of old arguments from the preceding decade from which were drawn, somewhat unsurprisingly, similar party-line conclusions. Holmes asserted that a congregation should 'receive none unto the Communion with them, but such as are manifested to the generality of them [believers] in the

\footnotetext{
96 Welde, An Answer to W. R. His Narration, 24.

97 Welde, An Answer to W. R. His Narration, 52.

98 Welde, An Answer to W. R. His Narration, 53.
} 
judgement of charity to be truely godly'. ${ }^{99}$ For the clergyman, 'This keeping out of gracelesse people from the Communion, by the Officers and Brethren of a Church is no new Doctrine, or practice, but ancient', thus staking a claim to ecclesiastical antiquity to shore up his argument for Congregationalism. ${ }^{100}$ On the contrary, Jeanes did not see any problems of decisive importance with mixed Communion when he declared that the 'admission of scandalous persons to the Lords Supper in a Presbyterated [Presbyterian structured] Church, is no ground or warrant to forbear the administration thereof' ${ }^{101}$ As long as a measure of care was taken to maintain purity surrounding the Lord's Supper such as 'cast[ing] out the scandalous' away from the Table or 'exhort[ing]' private members to examine themselves' prior to partaking of it, the church should not suspend administering the sacrament. ${ }^{102}$

\section{Conclusion}

The Presbyterians and Congregationalists, whose arguments on congregational membership and church purity we have explored above, formed the majority of the Puritan community. In late 1640 and early 1641, they were excited at the prospect of reforming the established Church of England. Yet they simultaneously recognised the need to maintain unity if they were to enjoy any kind of success in the reform efforts against their common enemy of Episcopalians and Royalists. Unity was not easy to come by, however. There was in fact so much potential for open disunity that the Presbyterian and Congregationalist ministerial leaders had to draw up a sort of self-denying pact. They met, we are told, at the clergyman Edmund Calamy's house in late 1641 to draw up an agreement to the effect that '(for advancing of the publike Cause of a happy Reformation) neyther side should Preach,

99 Nathaniel Holmes, The Mischiefe of Mixt Communions Fully Discussed. The Main Arguments of Both Sides Are Largely Canvased (London: 1650): 5. 'Communion' here seems most likely to be a reference to the sharing of the sacrament of the Lord's Supper, although the term may also denote common ecclesiastical membership and spiritual activity.

100 Holmes, Mischiefe of Mixt Communions, 5.

${ }^{101}$ Henry Jeanes, The Want of Church Government No Warrant for a Total Omission of the Lords Supper. Or, a Brief and Scholastical Debate of That Question, Which Hath So Wonderfully Perplexed Many, Both Ministers and People (London: 1650): 44. 102 Jeanes, Want of Church Government No Warrant, 45. 
Print, or Dispute, or otherwise act against other's way ... And this to continue till both sides, in a full meeting, did declare the contrary, and by mutuall consent set each other at liberty, touching these things. ${ }^{103}$ Still, when that agreement was broken, or was thought to have been broken, presumably with the publication of the Apologeticall Narration by the Congregationalists in early 1644 , the floodgates, it seems, opened up. After that time, the Puritan community as well as the general public were inundated with pamphlets criticising the shortcomings, or praising the merits, of either Presbyterianism or Congregationalism. The primary source of conflict proved to be ecclesiology and more specifically structures of church governance, as we have noted. For the Presbyterians, the hierarchical system of consistory, presbytery, and synods regulating the rhythms of church life was a non-negotiable principle, whilst the Congregationalists wanted to give each congregation the right to govern itself without outside interference. When both sides were unable, or unwilling, to compromise, religious toleration then emerged as another issue that would embroil the godly community in yet greater turmoil than before. ${ }^{104}$ Against this backdrop, historians have rightly paid significant attention to the two interconnected issues of ecclesiology and toleration. Yet what this article has sought to demonstrate is that adding fuel to the fire of controversy over church polity and religious liberty were the issues of congregational membership, purity of spiritual ordinances and integrity of the church. The polemicists in the controversy, whether Presbyterian or Congregationalist, had strong ideas about who should constitute a true congregation, how to safeguard the purity of divine ordinances, and the ways in which to maintain the church as a sanctified institution. For all the ink spilt over these interconnected issues, however, it may also be worth noting that there seems to have been much insular reasoning and cross-purpose argumentation as well. For instance, whilst Edwards had noted in 1641

103 John Vicars, The Schismatick Sifted (London: 1646): 6; see also A Letter of the Ministers of the City of London Presented the First of January 1645 (London: 1646): 1; Thomas Edwards, Antapologia, Or a Full Answer to the Apologeticall Narration (London: 1644): 240-45.

104 For background on the toleration controversy of the English Revolution, see John Coffey, Persecution and Toleration in Protestant England, 1558-1689 (Harlow: Longman, 2000); Alexandra Walsham, Charitable Hatred: Tolerance and Intolerance in England, 1500-1700 (Manchester: Manchester University Press, 2006); and Perez Zagorin, How the Idea of Religious Toleration Came to the West (Princeton: Princeton University Press, 2003). 
that unworthy persons would be kept away from the Lord's Table upon protests from wary congregational members once the church was reformed, Satisfaction Concerning Mixt Communions Unsatisfactory complained several years later that such protests would generally fall on deaf ears in a 'Church order' established along national lines. ${ }^{105}$ Yet, of course, the issues debated were real enough and the differences probably unbridgeable. Notwithstanding the fact that for most contemporary religious polemicists church purity was an ideal not to be attained in perfection in a fallen world, it ironically became an issue not open to much compromise. If ecclesiological differences over polity made difficult the task of finding a common ground on the Revolution's most controversial issue of religious freedom and unity among the Puritans as noted, the variant views of church purity and membership only served to complicate their endeavour to maintain that unity especially during an age when religion and politics were fused as one and when religious harmony was considered a bedrock of political stability. This turn of events left Puritan unity as merely an ideal, creating unwanted divisions amongst the Parliamentarians during the revolutionary decade and ultimately weakening the base of support for the Puritan regimes of the 1650 s, even perhaps facilitating the return of the Stuart monarchy in 1660.

105 Edwards, Reasons against Independant Government, 41; Anon., Satisfaction Concerning Mixt Communions, 10. 